\title{
PROFIL PEMIJAHAN DAN PERKEMBANGAN MORFOLOGI LARVA DAN YUWANA IKAN CLOWN HITAM (Amphiprion percula)
}

\author{
Daniar Kusumawati dan Ketut Maha Setiawati \\ Balai Besar Riset Perikanan Budidaya Laut \\ Jl. Br. Gondol, Kec. Gerokgak, Kab. Buleleng, Kotak Pos 140, Singaraja-Bali 81101 \\ E-mail: ornamental_research@yahoo.co.id
}

(Naskah diterima: 20 Agustus 2009; Disetujui publikasi: 25 Januari 2010)

\begin{abstract}
ABSTRAK
Amphiprion percula (ikan clown hitam atau clown Biak) merupakan salah satu spesies ikan hias laut yang umumnya ditangkap untuk tujuan komersial. Di samping itu, indikasi menurunnya jumlah ikan clown hitam disebabkan oleh kematian secara alami di alam sebesar $75 \%$ akibat tingkat agresivitas ikan clown hitam dalam mempertahankan wilayahnya. Tujuan penelitian ini adalah untuk mengetahui profil pemijahan dan perkembangan morfologi larva dan yuwana ikan clown hitam. 10 pasang koleksi induk diperoleh dari Biak. Pengamatan dilakukan selama 1 tahun yang meliputi pengamatan reproduksi biologis dan aspek morfologi dan perkembangan larva dan yuwana ikan clown hitam. Berdasarkan pengamatan diketahui bahwa $70 \%$ dari populasi induk ikan clown hitam telah berhasil bertelur dengan periode pemijahan 9-30 hari. Jumlah produksi telur yang diperoleh 25 hingga 2.244 butir. Jumlah telur dengan bobot induk betina berkorelasi positif. Masa inkubasi telur terjadi selama 6 hingga 7 hari. Sesaat setelah menetas, larva (D0) dapat mengkonsumsi rotifer. Artemia dan pakan pelet yang diberikan mulai dari D6 dan D17. Periode perkembangan larva sangat singkat yaitu 17 hari. Selama pengamatan ikan clown hitam menunjukkan pertumbuhan yang relatif lambat.
\end{abstract}

KATA KUNCl: Amphiprion percula, clown hitam, morfologi, larva, pemijahan

ABSTRACT: Spawning profile and morphology development of larvae and juvenile of black clown fish, Amphiprion percula. By: Daniar Kusumawati and Ketut Maha Setiawati

Amphiprion percula (black clown fish or clown Biak) is one of marine ornamental fish species captured mostly for commercial purposes. The depletion of black clown fish wild stock is caused by natural death. About 75\% mortality were caused by aggressiveness of black clown fish to each other in defending their territory. The research purposes were to know spawning profile and morphology development of larvae and juvenile of black clown fish. 10 pairs of broodstock were obtained from Biak coastal waters. Observations were conducted regularly for 1 year period to study the reproduction and biological aspects of the broodstock and morphological development of larvae and juvenile of black clown fish. The result showed that, $70 \%$ of population of black clown fish broodstock spawned successfully with spawning period from 9 to 30 days. The number of produced eggs was from 25 to 2,244. The number of eggs and weight of female broodstocks were correlated positively. The period of incubation of eggs lasted for 6 to 7 days. Newly hatched larvae (DO) can immediately feed on rotifer. Brine shrimp and commercial feed were given at D6 and D17. Period of larvae development was very short which lasted for 17 days. Black clown fish showed a relatively slow growth during the observation period. 
KEYWORDS: Amphiprion percula, black clownfish, morphology, spawning

\section{PENDAHULUAN}

Pada tahun 2005, ekspor global dan impor global ikan hias masing-masing tercatat senilai US $\$ 237.636 .000$ dan US $\$ 282.549 .000$ dengan komposisi $10 \%$ adalah ikan hias laut dan 1\%-10\% dari total tersebut diperoleh dari hasil budidaya (WCMC, 2008). Perkembangan perdagangan ikan hias laut yang sangat pesat akan berdampak pada populasinya di alam. Dihadirkannya program perbenihan secara terkontrol dengan kesempatan dapat memasuki dunia perdagangan dengan kontinuitas yang terjamin, menjadi upaya preventif mengurangi penangkapan di alam (Fernando et al., 2006).

Amphiprion percula atau ikan clown hitam atau clown Biak merupakan salah satu jenis ikan hias laut yang banyak ditangkap untuk tujuan komersial. Selain akibat dari penangkapan liar, indikasi menurunnya jumlah eksistensi ikan clown hitam di perairan juga disebabkan kematian secara alami. Ikan clown hitam bersifat agresif untuk mempertahankan daerahnya. Dalam 1 tahun populasi ikan clown hitam berkurang menjadi 25\% (Buston, 2003). Mengingat sifatnya yang sangat dinamis, banyak faktor yang akan mempengaruhi eksistensi ikan clown hitam di laut. Upaya perbenihan terkontrol perlu dilakukan untuk kesinambungan eksistensi ikan clown hitam. Untuk itu perlu dilakukan sebuah kajian mendalam tentang karakteristik ikan clown hitam sebagai informasi yang harus diperhatikan berkaitan dengan upaya perbenihan yang akan dilakukan nantinya. Tujuan penelitian ini adalah untuk mengetahui profil pemijahan dan perkembangan morfologi larva dan yuwana ikan clown hitam.

\section{BAHAN DAN METODE}

Penelitian terdiri atas 2 kegiatan, pertama adalah pengamatan aspek reproduksi dan kedua adalah pengamatan perkembangan morfologi larva dan yuwana ikan clown hitam hasil pemijahan di dalam akuarium.

\section{Profil Aspek Biologi Reproduksi Induk}

Induk yang diamati merupakan induk ikan clown hitam yang berasal dari Biak. Sepuluh pasang induk diletakkan dalam wadah akuarium ukuran $60 \mathrm{~cm} \times 40 \mathrm{~cm} \times 30 \mathrm{~cm}$ dengan sistem pemasukan dan pengeluaran air secara mengalir. Pemberian pakan pada induk berupa pelet komersil yang divariasikan dengan pakan tambahan berupa cacing laut (Nereis sp.), mysid, dan udang. Pemberian pakan dilakukan dengan frekuensi 2 kali sehari secara ad libitum. Kandungan utama pelet komersil terdiri atas 55\%-60\% protein, 10\%$15 \%$ lemak, >1,9\% serat. Parameter yang diamati adalah aspek biologi reproduksi dan produktivitas induk yang meliputi frekuensi dan jumlah telur, serta daya tetas telur.

\section{Morfologi Larva dan Yuwana}

Dari hasil pemijahan induk-induk ikan clown hitam, pengamatan berlanjut pada perkembangan larva dan yuwana. Telur-telur yang diperoleh berasal dari pemijahan alami di dalam akuarium. Telur dipanen pada hari ke-6 kemudian dipindahkan ke dalam bak polikarbonat kapasitas $200 \mathrm{~L}$ dengan volume air 150 liter yang sebelumnya telah diukur dengan menggunakan program winroof $\vee 5.0$ yang terhubung dengan mikroskop Nikon SMZ 1000 dengan perbesaran 4x yang dilengkapi dengan Nikon Digital Kamera Dxm 1200F. Pemberian pakan pada larva dan benih berupa fitoplankton, rotifer, dan artemia (Tabel 1) dengan konsentrasi masing-masing 2-4 × $10^{2}$ $\mathrm{sel} / \mathrm{mL}$, kisaran minimal 20 ekor $/ \mathrm{mL}$, dan kisaran minimal 10 ekor/ind. benih. Pemanenan yuwana dilakukan pada umur 20 hari.

Parameter yang diamati adalah pertumbuhan panjang dan bobot, isi perut, dan perkembangan lenturan notochord. Pengamatan pertumbuhan panjang pada larva D0D20 dilakukan dengan mengukur panjang total badan menggunakan mikroskop Nikon MZ 1000 dengan perbesaran yang disesuaikan dengan panjang larva. Sedangkan larva umur lebih dari D20 diukur dengan menggunakan mistar. Penimbangan bobot yuwana dilakukan mulai umur D35 dengan menggunakan timbangan digital Ohauss Scout Pro$2000 \times 0,1 \mathrm{~g}$. Pengamatan isi perut dilakukan setiap hari mulai D0-D1 0 kemudian dilanjutkan dengan selang hari tertentu hingga D17. Masing-masing pengamatan menggunakan sampel sebanyak 5-10 ekor. Pengamatan isi perut dilakukan dengan cara pembedahan menggunakan jarum untuk mengetahui 
Tabel 1. Jenis-jenis pakan yang diberikan selama pemeliharaan larva benih ikan clown hitam Amphiprion percula

Table 1. Types of feed for larval rearing of Amphiprion percula

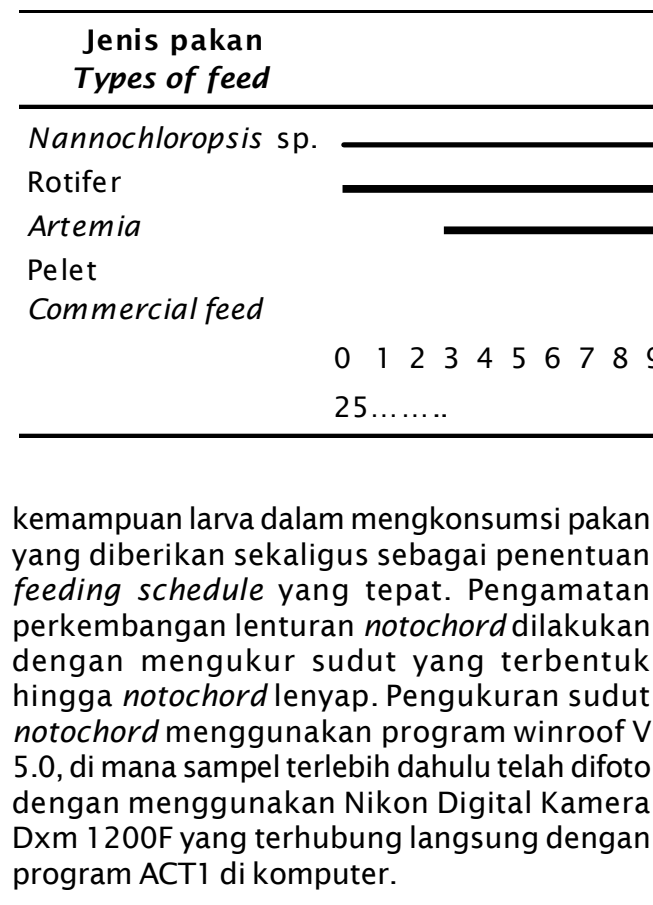

\section{Analisis Data}

Analisis data tingkah laku pemijahan dilakukan secara deskriptif. Sedangkan data produktivitas induk dan perkembangan morfologi larva dan yuwana dilakukan analisis regresi untuk mendapatkan korelasi tiap-tiap perkembangannya (Snedecor \& Cochran, 1989). Laju pertumbuhan bobot dan panjang dihitung menurut rumus SGR (Specific Growth Rate) (\%bw/day):

$$
\mathrm{SGR}=\frac{\ln \mathrm{Wt}-\operatorname{Ln} \mathrm{Wo}}{\mathrm{t}} \times 100 \%
$$

di mana Wo dan Wt merupakan bobot rata-rata biomassa awal dan akhir penelitian (initial and final average body weights) pada waktu $t$.

Sedangkan $h(\%)=\frac{h t-h o}{t} \times 100 \%$

di mana ho dan ht merupakan panjang rata-rata biomassa awal dan akhir penelitian (initial and final average body length) pada waktu $t$ (Effendi, 1997).

Volume kuning telur dan butir minyak dihitung menurut rumus:

$$
V e=\frac{\pi}{6} \times I \times h \quad \text { dan } \quad V=\frac{4}{3} \times \pi \times r^{3}
$$

di mana I dan $\mathrm{h}$ adalah panjang dan tinggi kuning telur (length and height of egg yolk) sedangkan $r$ adalah jari-jari butir minyak (Bonislawska et al., 2004).

\section{HASIL DAN BAHASAN}

\section{Profil Aspek Biologi Reproduksi Induk}

\section{Tingkah laku pemijahan}

Pasangan induk yang mulai menunjukkan adanya tanda-tanda pemijahan, terlihat dari pejantan yang membersihkan sarangnya yang masing-masing berupa segitiga semen, pipa paralon atau sudut akuarium. Pada induk betina, pada bagian abdomen semakin membesar dan berwarna pucat. Saat tiba waktu pemijahan pada posterior muncul urogenital papilla. Tidak seperti ikan laut pada umumnya yang selalu memijah pada dini hari, ikan clown memijah baik pagi, siang, sore, maupun malam hari. Betina yang memijah akan menempelkan telur pada sarang dan pejantan akan mengikuti induk betina untuk kemudian segera membuahi telur. Telur kemudian dijaga oleh pejantan dengan mengibaskan ekor dan sesekali membersihkan telur menggunakan mulutnya hingga telur menetas. Masa inkubasi telur adalah 6 hingga 7 hari. Pemanenan dilakukan pada hari keenam untuk menghindarkan kanibalisme induk terhadap larva yang menetas dalam akuarium. 


\section{Produktivitas induk}

Dari koleksi 10 pasangan induk ikan clown hitam, terdapat 7 pasang induk yang memijah dengan rata-rata ukuran induk betina $6,89 \pm$ $0,74 \mathrm{~cm}$ dan bobot $7,28 \pm 2,83 \mathrm{~g}$ sedangkan ukuran induk jantan $5,35 \pm 0,57 \mathrm{~cm}$ dan bobot 3,35 $\pm 0,96 \mathrm{~g}$ (Tabel 2). Berdasarkan frekuensi pemijahannya, nampak ikan clown hitam merupakan jenis ikan yang bertelur sepanjang tahun dengan periode siklus reproduksi 9-30 hari.

Masing-masing induk memiliki performa produktivitas yang berbeda-beda. Pasangan induk yang cukup produktif yaitu pasangan induk PT 2, PT 5, PT 7, dan PT 10 di mana induk ini mampu memijah dengan frekuensi rata-rata 2-3 kali dalam sebulan dan memijah sepanjang tahun dengan jumlah rata-rata telur yang dipijahkan sebesar 640 butir/ind. tiap satu kali pemijahan dengan derajat tetas yang juga cukup tinggi (>60\%). Pasangan induk PT 3, PT 8 , dan PT 9 merupakan pasangan induk yang kurang produktif dengan pola pemijahan yang tidak kontinu dengan jumlah rata-rata telur yang dipijahkan sebesar 112 butir/ind. tiap satu kali pemijahan dan derajat tetas telur rendah (<25\%). Pada pasangan induk PT 8 dan PT 9, tercatat adanya indikasi kanibalisme induk terhadap telur sehingga pemanenan tidak dapat dilakukan. Indikasi kanibalisme disebabkan telur terlepas dari sarang ketika induk jantan mengibaskan ekor sebagai bagian dari penjagaan telur.
Terdapat korelasi yang rendah antara jumlah telur dengan daya tetas telur $(R=0,031)$ dengan nilai persamaan logaritma $y=4,537$ $\ln (x)+37,66$ (Gambar 1). Apabila jumlah telur yang dihasilkan dikorelasikan dengan bobot badan induk betina, nampak hubungan polynomial dengan persamaan $y=302,8 x^{2}$ $4613 x+18406$ dengan nilai $R^{2}=0,504$ (Gambar 2). Berdasarkan korelasi tersebut diketahui bahwa pasangan induk yang memijah dengan ukuran bobot $6,87 \mathrm{~g}$ akan menghasilkan jumlah telur minimal 1.003 butir. Nampaknya ada faktor lain yang perlu dipertimbangkan selain ukuran bobot induk betina yang mampu mempengaruhi produktivitas ikan clown hitam yaitu umur dan fertilitas dari pasangan induk (Rattanayuvankorn et al., 2005). Mengingat induk berasal dari alam, korelasi umur maupun tingkat fertilitas pasangan induk terhadap tingkat produktivitas belum dapat diketahui.

\section{Profil Perkembangan Morfologi Larva dan Yuwana}

\section{Morfologi larva}

Telur yang dipijahkan berbentuk lonjong dengan kisaran ukuran panjang 2,21 $\pm 0,03$ $\mathrm{mm}$ dan lebar telur $0,89 \pm 0,01 \mathrm{~mm}$, panjang kuning telur $0,84 \pm 0,04 \mathrm{~mm}$ dan lebar 0,60 \pm $0,03 \mathrm{~mm}$ serta diameter butir minyak $0,19 \pm$ $0,07 \mathrm{~mm}$. Volume kuning telur dan butir minyak masing-masing $0,15 \mathrm{~mm}^{3}$ dan $0,03 \mathrm{~mm}^{3}$. Masa inkubasi telur ikan clown hitam dari awal

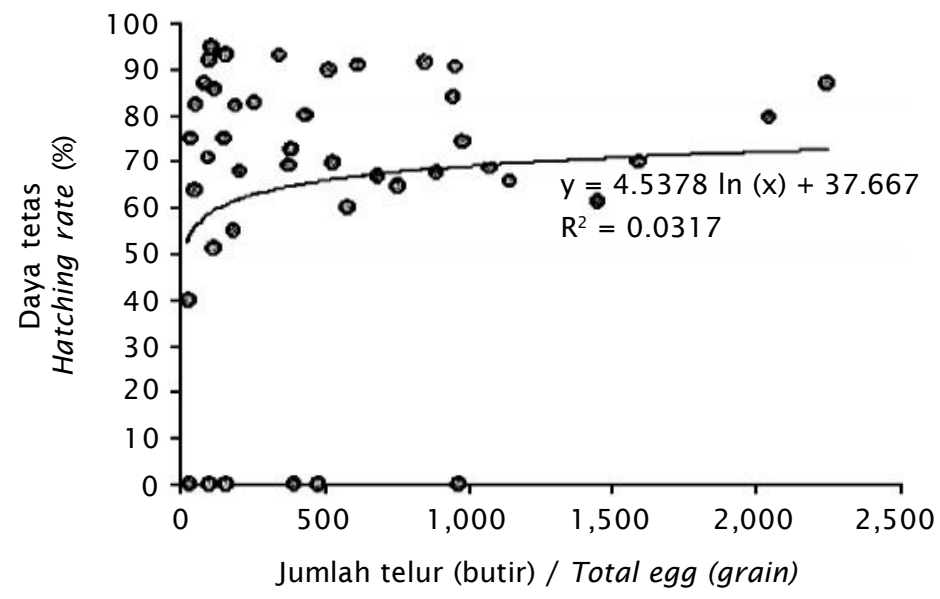

Gambar 1. Korelasi antara jumlah telur dengan daya tetas

Figure 1. Correlation between number of eggs and hatching rate 


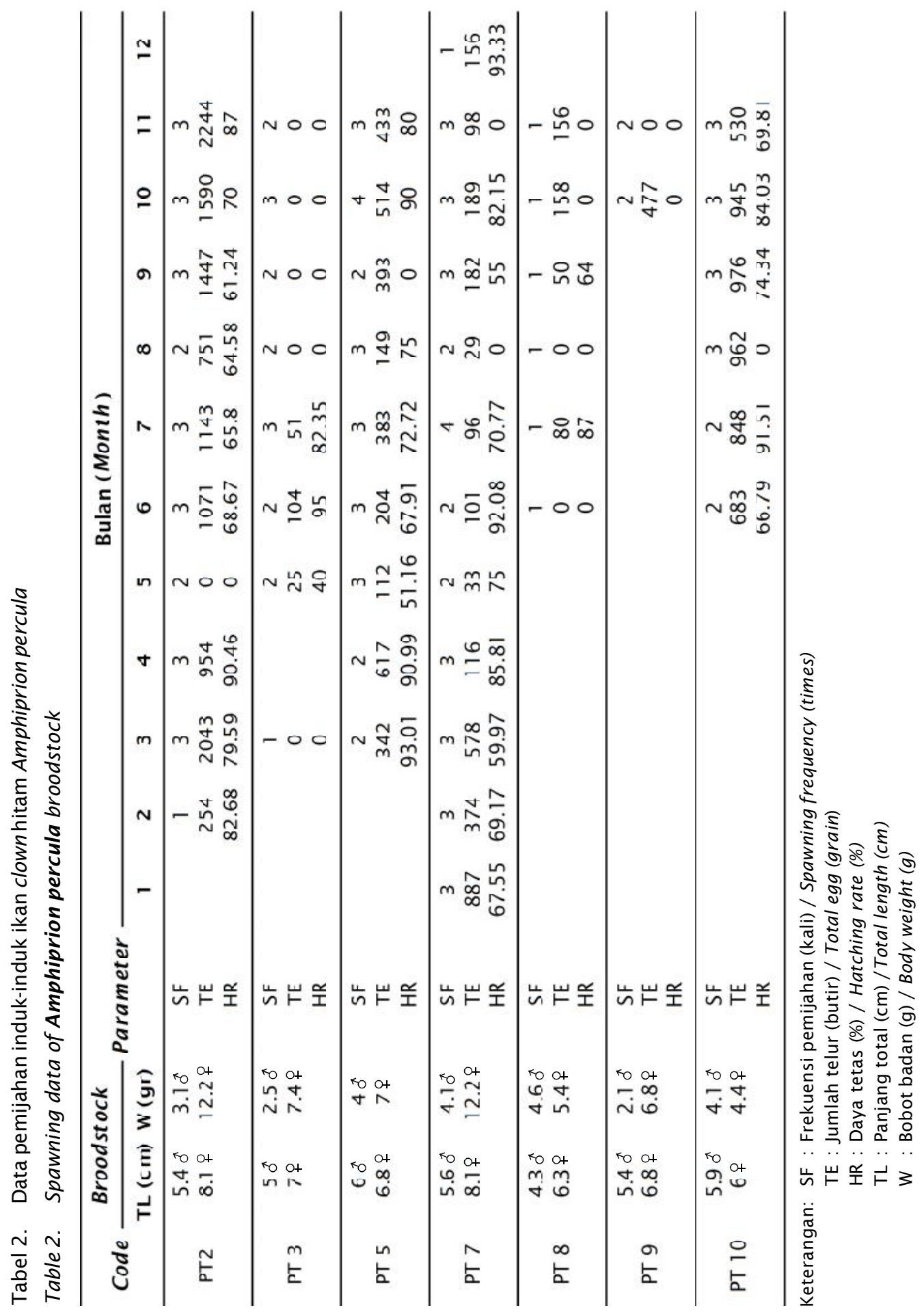




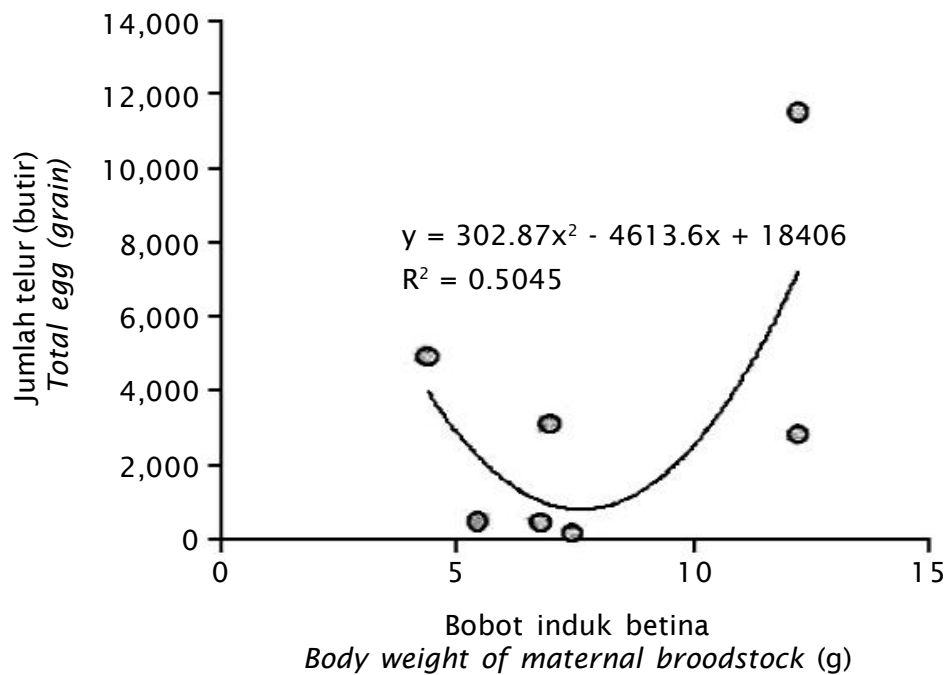

Gambar 2. Korelasi antara bobot induk betina dengan jumlah telur yang dipijahkan

Figure 2. Correlation between weight of female and number of eggs produced

dipijahkan sampai dengan menetas sama dengan masa inkubasi telur dari jenis ikan clown biasa (Amphiprion ocellaris) (Kusumawati et al., 2008; Liew et al., 2006) dan Amphiprion polymnus (Rattanayuvakorn et al., 2005) yaitu 6 hingga 7 hari. Pada awal pemijahan telur akan berwarna orange dan terus berubah hingga menjadi perak seiring dengan lamanya inkubasi. Warna silver yang muncul mengindikasikan bintik mata telah terbentuk, dan pada hari ke- 6 hingga 7 warna silver semakin bening yang mengindikasikan telur harus segera dipanen.

Larva yang baru menetas (D0) memiliki cadangan makanan berupa kuning telur dan butir minyak yang terserap habis hingga umur D2. Penyerapan kuning telur dan butir minyak ini masing-masing mengikuti hubungan polynomial dengan mengikuti persamaan $\mathrm{y}=$ $0,021 x^{2}-0,066 x+0,046$ dengan nilai $R^{2}=1$ dan $y=0,030 x^{2}-0,133 x+0,145$ dengan nilai $R^{2}=1$ (Gambar 3). Pigmentasi pada kulit larva berupa bintik hitam yang muncul pada umur D0 hingga D15. Pigmentasi bintik hitam terus mengalami pemudaran dan hilang sempurna pada umur D17. Pada umur D17 inilah pigmentasi ban putih pada bagian kepala mulai muncul dan terus menguat seiring dengan bertambahnya umur yuwana. Perubahan metamorfosis fase larva menjadi yuwana ditentukan dari hilangnya notochord pada bagian ekor. Hal ini diasumsikan bahwa yuwana telah mampu berenang dengan sempurna. Hilangnya notochord pada bagian ekor terjadi ada umur D17. Korelasi umur dan perkembangan derajat lenturan notochord mengikuti hubungan linear dengan persamaan $y=-5,508 x+171,2$ dengan nilai $R^{2}=0,547$ (Gambar 4a). Sedangkan korelasi panjang total dengan perkembangan derajat lenturan notochord juga mengikuti hubungan linear dengan persamaan $y=-158,3 x+229,6$ dengan nilai $\mathrm{R}^{2}=0,478$ (Gambar $\left.4 \mathrm{~b}\right)$.

\section{Pertumbuhan Panjang dan Bobot}

Laju pertumbuhan panjang larva dan yuwana mulai D0 hingga D1 50 hari (5 bulan) mengikuti hubungan polynomial dengan persamaan $y=-7 E-05 x^{2}+0,020 x+0,481$ dengan nilai $R^{2}=0,967$ (Gambar 5a). Sedangkan pertumbuhan bobot badan mengikuti hubungan logaritma dengan persamaan $\mathrm{y}=$ $0,029 \mathrm{e}^{0,013 x}$ dengan nilai $R^{2}=0,816$ (Gambar 5a). Laju pertumbuhan bobot dan panjang ikan clown relatif sangat lambat apabila dibandingkan dengan ikan-ikan lain seperti kerapu pasir dengan laju pertumbuhan panjang 4,50\%/hari (Hutapea \& Slamet, 2007). Laju pertumbuhan panjang dan bobot ikan clown adalah 1,18\%/hari dan 1,25\%bw/hari. 


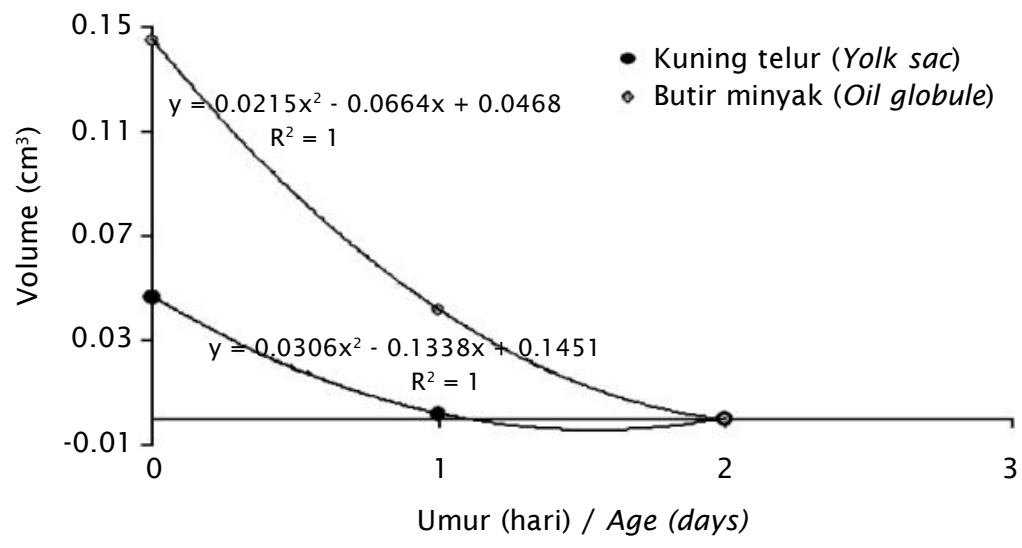

Gambar 3. Laju penyerapan endogenus larva dan benih ikan clown hitam Amphiprion percula

Figure 3. The rate of endogenous absorption of Amphiprion percula
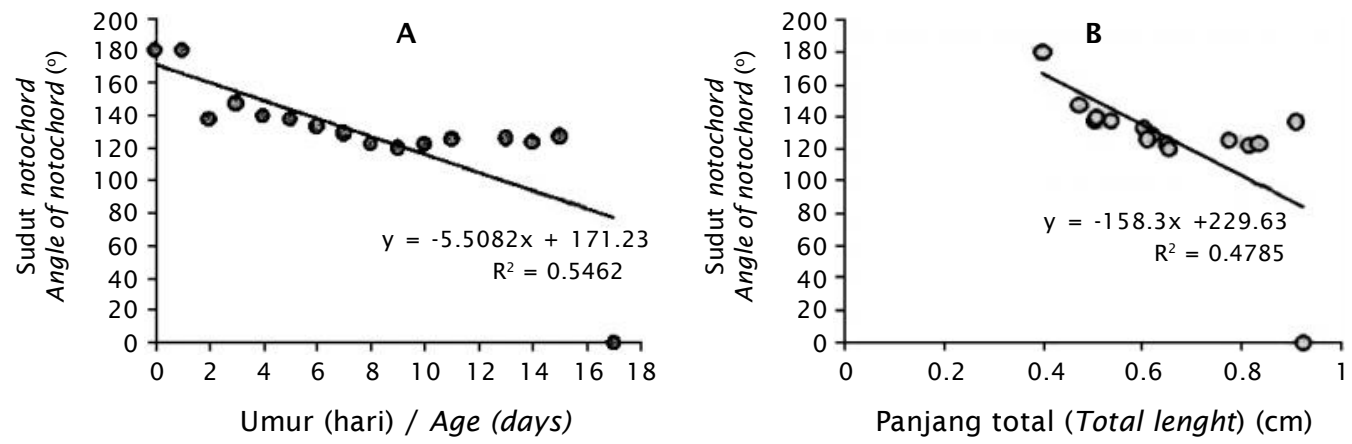

Gambar 4. Perkembangan lenturan sudut notochord (a). Korelasi antara lenturan sudut notochord dengan panjang badan ikan clown hitam Amphiprion percula (b)

Figure 4. Notochord angle development (a). Correlation between the notochord angle and total length of Amphiprion percula (b)
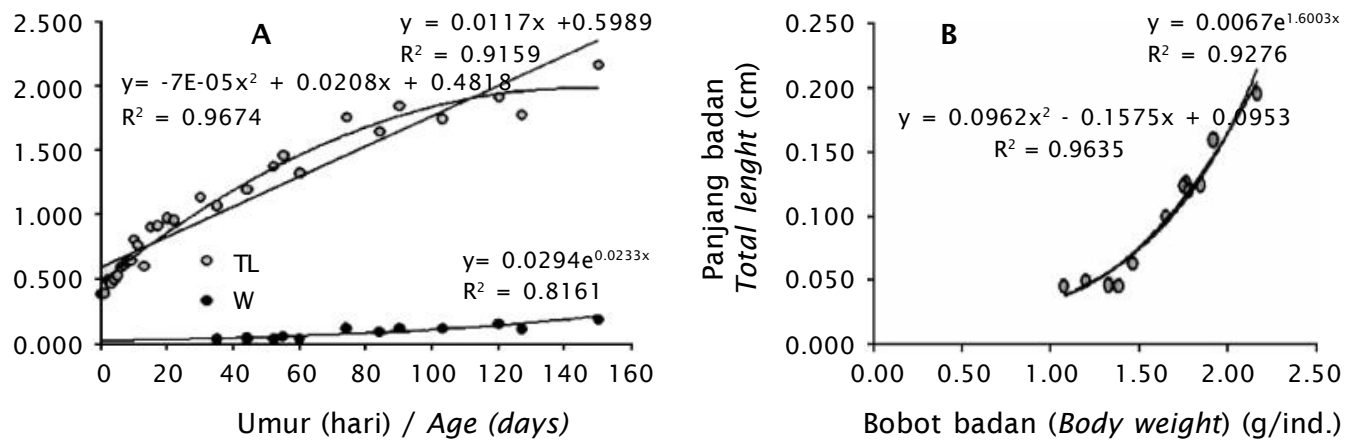

Gambar 5. Kecenderungan pertumbuhan larva dan benih ikan clown hitam Amphiprion percula (a). Korelasi panjang dengan bobot badan ikan clown hitam Amphiprion percula (b)

Figure 5. Trend of larvae and yuwana development of Amphiprion percula (a). Correlation between the total length and body weight of Amphiprion percula (b) 


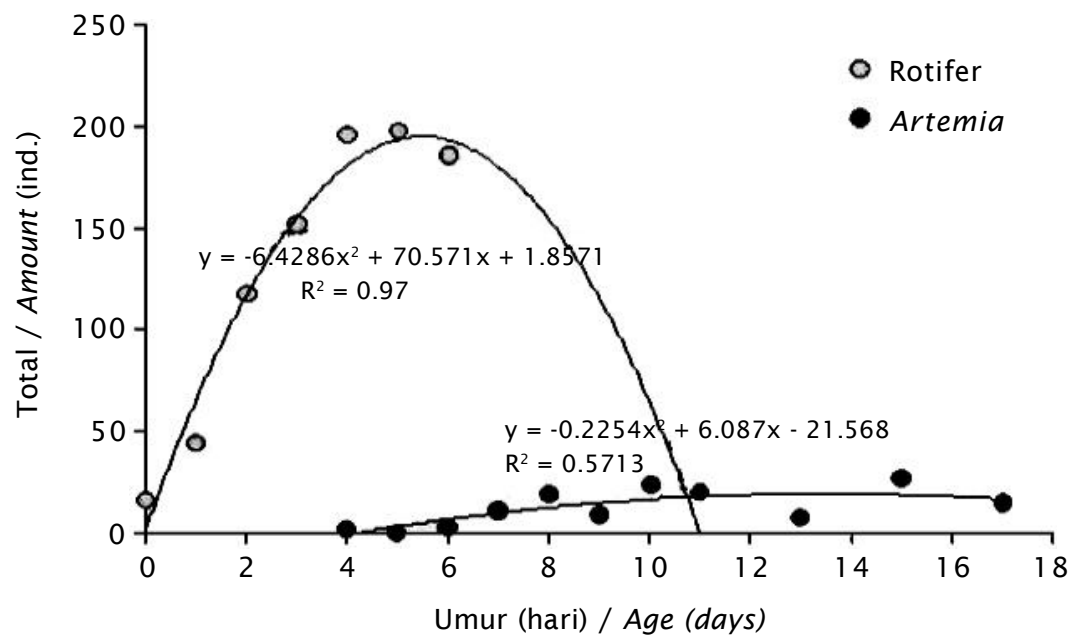

Gambar 6. Isi perut pada larva dan yuwana ikan clown hitam Amphiprion percula

Figure 6. Stomach content of larvae and yuwana of Amphiprion percula

Korelasi antara pertumbuhan panjang dan bobot yuwana ikan clown hitam mengikuti hubungan polynomial dengan persamaan $\mathrm{y}=$ $0,096 x^{2}-0,157 x+0,095$ dengan nilai $R^{2}=0,963$ (Gambar $5 b$ ). Pada umumnya hubungan panjang bobot ikan mengikuti hubungan eksponensial yaitu $\mathrm{W}=\mathrm{aL}^{\mathrm{b}}(\mathrm{W}=$ weight, $\mathrm{L}=$ length, $\mathrm{a}$ dan $\mathrm{b}=$ konstanta), tetapi tidak demikian dengan ikan clown hitam. Namun mengingat pertumbuhan merupakan transformasi dari garis lurus yang terus naik dan hingga pada waktu tertentu akan terus stabil, maka rumus eksponensial harus digunakan (Petrakis \& Stergiou, 1995). Hubungan panjang bobot ikan clown didapatkan $\mathrm{y}=0,0006 \mathrm{e}^{1,6 x}$ dengan nilai $\mathrm{R}^{2}=0,927$, nilai $b=1,6$ dan $a=0,0006$. Pertumbuhan bobot ikan clown hitam hingga D150 lebih cepat dibandingkan pertumbuhan panjang badannya. Permintaan benih ikan clown hitam di pasaran umumnya berkisar antara 2 hingga $3 \mathrm{~cm}$. Untuk mencapai ukuran tersebut memerlukan waktu 130 hingga 200 hari atau berkisar antara 4 hingga 7 bulan pemeliharaan.

\section{Isi perut larva dan yuwana}

Larva D0 sudah dapat mengkonsumsi pakan alami berupa rotifer hal ini terlihat dari hasil pembedahan perut di mana besar bukaan optimal mulut larva berkisar $75^{\circ}$. Sifat ini sangat berbeda dibandingkan dengan jenis-jenis ikan laut khususnya ikan konsumsi seperti ikan kerapu pasir yang baru dapat mengkonsumsi rotifer pada umur D3 (Hutapea \& Slamet, 2007), atau ikan napoleon yang mulai mengkonsumsi rotifer pada D1 5 (Hutapea \& Slamet, 2006). Kemampuan tersebut berkaitan dengan perkembangan morfologi dari ikan clown, di mana perkembangan larva dimulai saat di dalam telur, sementara ikan laut lain perkembangan larva dimulai ketika menetas. Selain itu, tingkat laju penyerapan endogenous larva ikan clown relatif cepat dibandingkan dengan ikan laut lainnya, di mana cadangan makanan berupa kuning telur terserap habis pada umur D1, sehingga rotifer sudah harus diberikan pada saat larva D0.

Mulai D0 hingga D5 jumlah rotifer yang dimakan terus meningkat. Memasuki umur D6, jumlah rotifer yang terdapat dalam perut mulai berkurang. Titik optimum jumlah rotifer dalam isi perut larva berada pada level umur D5, hal ini menunjukkan bahwa di atas umur D6, larva dapat diberikan artemia sebagai pengganti rotifer (Gambar 6). Sementara itu, pada umur D4, di dalam isi perut larva mulai ditemukan artemia dalam jumlah kecil dan terus meningkat seiring dengan bertambahnya umur larva. Titik optimum jumlah artemia yang ditemukan dalam perut larva ikan clown hitam berada pada umur D13 (Gambar 6). Hal ini menunjukkan bahwa pada umur di atas D1 4 ikan clown hitam mulai dapat diberikan pakan pelet. 


\section{KESIMPULAN}

Berdasarkan hasil penelitian ini, 70\% dari total populasi induk telah berhasil memijah. Periode pemijahan berlangsung 9 hingga 30 hari. Jumlah telur yang dipijahkan bervariasi mulai 25 hingga 2.244 butir. Jumlah telur yang dipijahkan berkorelasi positif dengan bobot induk betina. Masa inkubasi telur terjadi selama 6 hingga 7 hari. Larva yang menetas (D0) dapat mengkonsumsi makanan alami berupa rotifer. Pemberian pakan tambahan berupa artemia dan pelet dimulai pada masing-masing umur D6 dan D14. Masa perkembangan larva relatif singkat yaitu 17 hari, kemudian larva berubah menjadi yuwana. Selama pengamatan, ikan clown hitam ini menunjukkan laju pertumbuhan yang relatif sangat lambat. Pertumbuhan bobot ikan clown lebih cepat dibandingkan pertumbuhan panjangnya.

\section{DAFTAR ACUAN}

Bonislawska, M., Korzelecka-Orkisz, A., Winnicki, A., Formicki, K., \& Szaniawska, D. 2004. Morpho-physiological aspects of the embryonic development of ruffe, Gymnocephalus cernuus (L.) under different thermal conditions. Actha Ichtyologica Et Piscatoria, 34(1): 51-72. http:// www.aiep.pl.34.1.6. Diunduh pada tanggal 22-8-2007.

Buston, P.M. 2003. Mortality is associated with social rank in the Clown Anemonfish (Amphiprion percula). Marine Biology, 143: 811-815. http://ieg.ebd.csic.es. Diunduh pada tanggal 23-3-2009.

Effendi, M.I. 1997. Biologi perikanan. Yayasan Pustaka Nusatama. Yogyakarta, 163 pp.

Fernando, O.J, Raja, K., \& Balasubramanian, T. 2006. Studies on Clown fish Amphiprion sebae with various feed combinations under recirculating aquarium condition. International Journal of Zoological Research, 2(4): 376-381. http://www.scialert.net. Diunduh pada tanggal 23-3-2009.
Hutapea,J.H. \& Slamet, B. 2006. Morphological development of Napoleon Wrasse Cheilinus undulates larvae. Indonesian Aquaculture Journal, 1(2): 145-151.

Hutapea, J.H. \& Slamet, B. 2007. Perkembangan morfologi larva ikan kerapu pasir Epinepelus corallicola (Valenciennes, 1828). Prosiding Seminar Nasional Kelautan III. Pembangunan Kelautan Berbasis IPTEK dalam Rangka Peningkatan Kesejahteraan Masyarakat Pesisir. Universitas Hang Tuah. Surabaya. hlm. 27-34.

Kusumawati, Wardoyo, D., \& Setiawati, K.M. 2008. Perkembangan embrio ikan Clown Amphiprion ocellaris pada suhu dan salinitas inkubasi berbeda. Prosiding Seminar Nasional Tahunan V. Hasil Penelitian Perikanan dan Kelautan. Universitas Gadjah Mada. Yogjakarta, hlm. 1-6.

Liew, H.J., Ambak, M.A., \& Abol-Munafi, A.B. 2006. Embryonic development of Clown fish Amphiprion ocellaris under laboratory conditions. Journal of Sustainability Science and Management, 1(1): 64-73.

Petrakis, G. \& Stergiou, K.I. 1995. Weight-length relationships for 33 fish species in Greek waters. Fisheries Research, 21: 465-469. http://ichtyology.bio.auth.gr. Diunduh pada tanggal 31-3-2009.

Rattanayuvakorn, S., Mungkornkarn, P., Thongpan, A., \& Chatchavalvanich. 2005. Embryonic development of saddleback anemonfish, Amphiprion polymnus, Linnaeus (1758). http://genetics.sci.ku.ac. th. Diunduh pada tanggal 19-11-2008.

Snedecor, G.W. \& W.G. Cochran. 1989. Statistical method. Eight Edition. Wiley-Blackwell, $503 \mathrm{pp}$.

WCMC. 2008. Monitoring of international trade in ornamental fish. European Cominission. http://www.unep.wcmc.org. Diunduh pada tanggal 3-3-2009. 